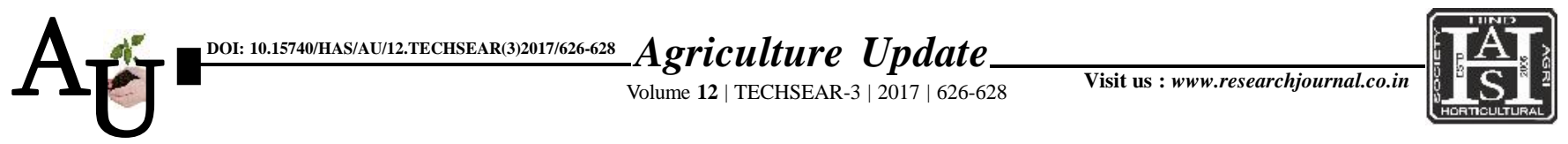

— e ISSN-0976-6847

\title{
Research Article: Impacts of nutrient management and chlormequat application on economics of maize
}

\author{
V.V. PATIL, H.V. PAWAR AND R.K. SATHE
}

Article Chronicle:

Received :

10.07.2017;

Accepted :

25.07.2017

SUMMARY : The field experiment was conducted during Kharif season of 2013-2014 on field No.10 of Agronomy farm, College of Agriculture, Nagpur. The experiment was laid out in Split plot design with twelve treatment combinations comprising three levels of nutrient management viz., $\mathrm{N}_{1}-100 \%$ RDF (120:60:30 NPK kg ha-1), $\mathrm{N}_{2}-125 \%$ RDF (150:75:37.5 $\mathrm{NPK} \mathrm{kg} \mathrm{ha}^{-1}$ ) and $\mathrm{N}_{3}-150 \%$ RDF (180:90:45 NPK kg $\left.\mathrm{ha}^{-1}\right)$ and four foliar applications of chlormequat viz., $\mathrm{C}_{0}$ (No application), $\mathrm{C}_{1}(500 \mathrm{ppm}), \mathrm{C}_{2}(750 \mathrm{ppm})$ and $\mathrm{C}_{3}(1000 \mathrm{ppm})$ concentrations, forming 12 treatment combinations replicated three times.Application of $150 \% \mathrm{RDF}$ and $1000 \mathrm{ppm}$ chlormequat application to maize crop recorded highest gross monetary as well as net monetary return and $\mathrm{B}$ : $\mathrm{C}$ ratio.

How to cite this article : Patil, V.V., Pawar, H.V. and Sathe, R.K. (2017). Impacts of nutrient management and chlormequat application on economics of maize. Agric. Update, 12(TECHSEAR-3) : 626-628; DOI: 10.15740/ HAS/AU/12.TECHSEAR(3)2017/626-628.

Key Words :

Maize, Nutrient

management,

Chlormequat,

economics

Author for correspondence :

V.V.PATIL

Agronomy Section,

College of Agriculture,

NAGPUR (M.S.) INDIA

See end of the article for

authors' affiliations 